Research Article

\title{
Epidemiological determinants of age for effective cervical and breast cancer screening in menopausal women
}

\author{
Bharti Prakash, Meenakshi Gahlot*, Laxmi Yadav
}

Department of Zoology, S.P.C. Govt. College Ajmer, Rajasthan, India

Received: 10 December 2015

Revised: 12 January 2016

Accepted: 23 January 2016

\author{
*Correspondence: \\ Dr. Meenakshi Gahlot, \\ E-mail: meenakshi_gahlot@yahoo.in
}

Copyright: () the author(s), publisher and licensee Medip Academy. This is an open-access article distributed under the terms of the Creative Commons Attribution Non-Commercial License, which permits unrestricted non-commercial use, distribution, and reproduction in any medium, provided the original work is properly cited.

\begin{abstract}
Background: Breast and cervical cancer screening play an important role in reducing cancer mortality. Family history and other screening tools are helpful in reducing cancer burden. Present study is focused on the impact of early screening of cervical and breast cancer on incidence of both cancers with focus on menopausal women ageing 30-70.

Methods: It is an epidemiological study in Ajmer municipal area with retrospective and prospective recorded data on cervical and breast cancer screening. Factors which are not considered may drive the observed association Participants of current study were registered and diagnosed with cervical and breast cancer in different hospital of Ajmer municipal area between January 2011-March 2015.468 women aged 30-70 with invasive cervical and breast cancer diagnosed in different major hospitals of Ajmer municipal area. Control participants were matched on area of residence and by age-group. Association between cancer and screening at particular ages are co-related to determine odd ratios.

Results: There is evidence that screening was associated with a $32 \%$ reduction of cervical cancer and $48 \%$ reduction of breast cancer in women aged 45 . There is $41 \%$ reduction of cervical cancer and $52 \%$ reduction of breast cancer in women aged 55.There is no evidence of reduction in incidence of cervical and breast cancer at 35 (Odd Ratio 1.12, $95 \%$ confidence interval 0.84 to 1.52 ). Screening in later age reduces incidence and mortality from cervical and breast cancer.

Conclusions: To significantly reduce the breast and cervical cancer mortality, screening should be sturdily intensified to improve long term effectiveness. Quality assessment of early screening should be done via early indicators. New screening modalities have been introduced and some of them should be gradually incorporated into society practice.
\end{abstract}

Keywords: Cancer screening, Cervical cancer, Breast cancer, Menopause

\section{INTRODUCTION}

Cancer has become a huge threat to human population. According to Indian census data, cancer is the second most common disease in India. This is the result of lacking better preventive, diagnostic and treatment strategies. Although new diagnostic and treatment strategies are introducing but it is still not up to the mark for early eradications of cancer. ${ }^{1}$ Cancer has become a huge threat to human population. According to Indian census data, cancer is the second most common disease in India. This is the result of lacking better preventive, diagnostic and treatment strategies. Although new diagnostic and treatment strategies are introducing but it is still not up to the mark for early eradications of cancer. It is predominantly a malignancy, which has been increasing in incidence in some population over the past few decades due to improvement in screening. Breast cancer is a malignant tumor that grows into surrounding 
tissues and spread to distant area of the body. ${ }^{2}$ The female breast is made up of milk producing glands (lobules), tiny tubes that carry the milk from the lobules to the nipple (ducts) and fatty tissue, connective tissue, lymphatic vessels and blood vessels. Breast cancer is the most common cancer in developed countries and second leading cause of cancer death in women (after lung cancer). ${ }^{3}$

Lymphatic system includes small beans shaped immune system cells called lymph nodes. It is connected with lymphatic vessels under the arms (axillaries nodes).Some lymph nodes connected to lymphatic vessels inside the chest called internal mammary nodes. Cancer is predominantly a malignancy, which have been increasing in incidence in some population over the past few decades due to improvement in screening. ${ }^{4}$ Cancer screening is an important landmark to detect cancer before appearing symptoms. It includes various tests such as biopsy, pap smear test, urine test and blood test. It is useful in cancer prevention, early detection and early treatment. Early diagnosis may useful in higher rate of successful treatment. People with family history which are at higher risk of developing cancer can be screen with Selective cancer screening.

It is important for reducing cancer at affordable cost to reduce economic burden of India. Women go for cancer screening at later stage once they reach in advance stage of cancer. Screening must be safe and effective. ${ }^{5}$ With the rising number of public health issues facing the public today, comprehensive and clear health communication approach is becoming even more important to ensure the efficient and safe delivery of health services. Proper implementation of health care policy is a unique skill to bridge the gap between the consumers and the health system. It could be achieved by optimizing and creating relationships and community partnerships.

\section{METHODS}

It is an observational epidemiological study. The research was done by using data of women breast and cervical cancer collected through different hospitals of Ajmer, which help in the progress of research scale. The next stage comprises of qualitative data collected through questionnaire. Cancer research approach describes the qualitative data collection approaches and scale development procedure. It proportionally develops to quantitative aspects of cancer research with the section on data collection method, with the sampling approach. The non- response bias issues and data cleaning process would explain in this section. After this the statistical methods and tools probably discussed for analysis. Case control study has several biases. ${ }^{5}$ Factors which are not considered may drive the observed association Participants of current study were registered and diagnosed with cervical and breast cancer in different hospital of Ajmer municipal area between January 2011March 2015.These women have a record in cervical and breast screening call and recall system. All control women were matched with experimental women on age and residential area. They were selected at random order. We associated the effect of screening separately by cancer stage. Finally, we considered both all available data and only data obtained subsequently to examine possible trends associated with changes in screening practice.

To understand the reason for screening being more effective in older women we also looked, by the proportion of cases classified as screen detected, never screened or lapse.

\section{Statistical analysis}

To estimate the association between screening and incidence of cervical and breast cancer conditional logistic regression is used. Association between them is expressed as odds ratio for developing cervical and breast cancer. All age range is in inclusive series. Odds ratios are used to compare the relative odds of the occurrence of the outcome of disease. ${ }^{7}$ The odds ratio can also be used to determine whether a particular exposure is a risk factor for a particular outcome and to compare the magnitude of various risk factors for that outcome. The $95 \%$ confidence interval is used to estimate the precision of the odds ratio.

\section{RESULTS}

Table 1: Distribution of cancer stage IA and IB according to screening classification. Figures are in number of women $(\mathrm{N}=468)$.

\begin{tabular}{|llllll|}
\hline Screening & $\mathbf{3 0 - 4 0}$ & $\mathbf{4 0 - 5 0}$ & $\mathbf{5 0 - 6 0}$ & $\mathbf{6 0 - 7 0}$ & Total \\
\hline $\begin{array}{l}\text { First } \\
\text { Screened }\end{array}$ & 28 & 41 & 27 & 32 & 128 \\
\hline $\begin{array}{l}\text { Never } \\
\text { Screened }\end{array}$ & 31 & 46 & 29 & 22 & 143 \\
\hline $\begin{array}{l}\text { Previously } \\
\text { Screened }\end{array}$ & 38 & 27 & 14 & 10 & 89 \\
\hline $\begin{array}{l}\text { After } \\
\text { Abnormal } \\
\text { Cytology }\end{array}$ & 29 & 28 & 26 & 25 & 108 \\
\hline
\end{tabular}

Our study confirms that cervical and breast cancer screening in women aged 30-35 is less effective than in older women. By studying the effect of screening in smaller age groups, it indicate that the efficacy of screening decreases with decreasing age, even within the age range $30-35$ (Table 1). There is evidence that screening was associated with a $32 \%$ reduction of cervical cancer (Figure 2) and $48 \%$ reduction of breast cancer in women aged 45 (Figure 3). There is $41 \%$ reduction of cervical cancer and $52 \%$ reduction of breast cancer in women aged 55. There is no evidence of reduction in incidence of cervical and breast cancer at 35 (Odd Ratio $1.12,95 \%$ confidence interval 0.84 to 1.52 ). 
Screening in later age reduces incidence and mortality from cervical and breast cancer.

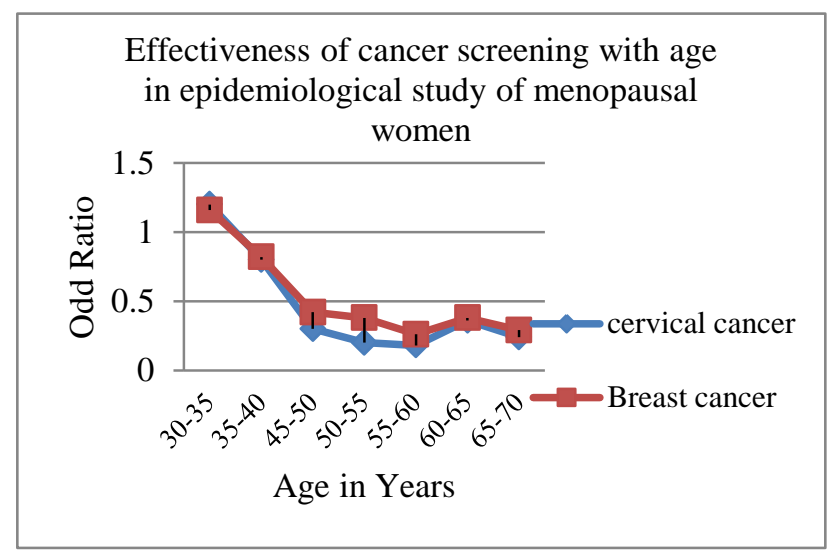

Figure 1: Odd ratio for developing cervical and breast cancer in those screened in a given age band compared with not screened in that age band (Between Jan 2011- Jan 2015).

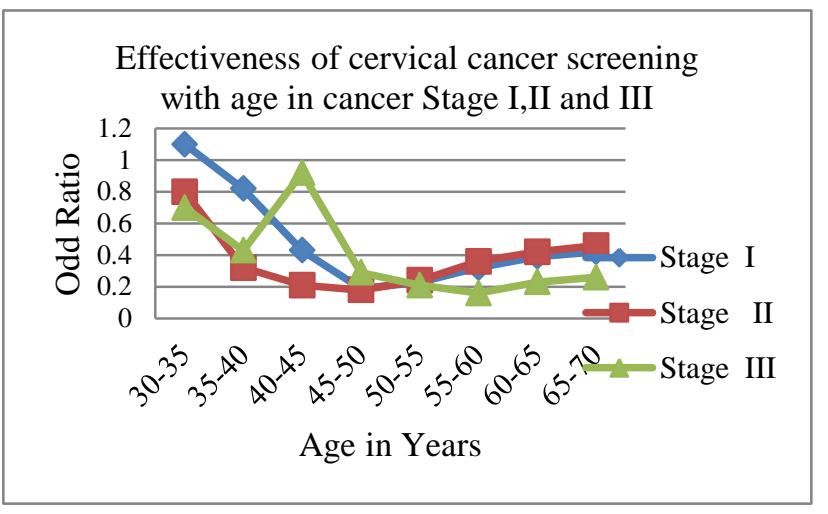

Figure 2: Effect of cancer stage on odd ratio of developing cervical cancer in those screened in that age band with not screened in that age band (Jan 2011- Jan 2015).

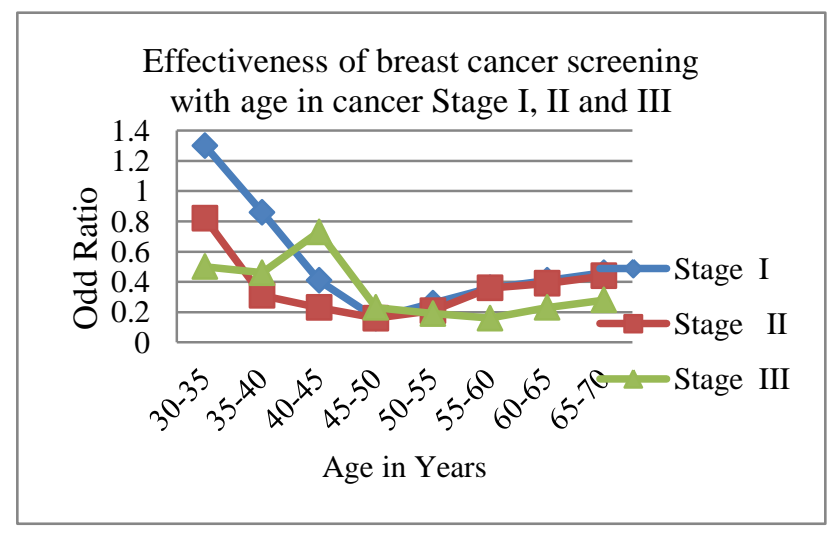

Figure 3: Effect of cancer stage on odd ratio of developing breast cancer in those screened in that age band with not screened in that age band (Jan 2011-Jan 2015)
The study is design to eliminate most of the biases that affect case-control studies, our observed associations are either causal or the result of confounding. The association in different age bands within the same study argues strongly that these effects are real. It may be biological reasons for cervical and breast screening working better in older women. Specificity of screening is less in women aged 30-35 because human papilloma - virus (HPV) infections are so much more common in younger women. However it does not; explain why the sensitivity of screening should be less.

\section{DISCUSSION}

Review of the screening histories of women aged 30-35 with a diagnosis of cervical and breast cancer suggests that some of the cancers occurred through a lack of screening. This means that the opportunities for detecting the small proportion of cervical and breast cancer grade III in women in their early $30 \mathrm{~s}$ that will progress to cancer within at most a few years are small. In most cases of cervical and breast grade III detected will be slow growing and could safely be left for several years; but the rare cases that are progressing rapidly will probably be missed in sampling. ${ }^{9}$ Development of screening strategies based on the estimation of the burden of cancer should be attributable to risk factor at regional level. ${ }^{10}$ The strength of screening should be explain and examine in a systematic way. The association, which is not reflective of an original causal chain, will not provide a strong basis of dropping cancer burden. Assessment of screening role in reducing cancer burden should describe upon the best available facts.

\section{CONCLUSION}

To significantly reduce the breast and cervical cancer mortality, screening should be sturdily intensified to improve long term effectiveness. Quality assessment of early screening should be done via early indicators. New screening modalities have been introduced and some of them should be gradually incorporated into society practice.

\section{ACKNOWLEDGEMENTS}

We would like to acknowledge and express our sincere gratitude and thanks to Dr. U. S. Mathur (oncologist and in- charge of cancer research centre J.L.N. Medical College, Ajmer) for his sincere support in data collection. We are thankful to department of Zoology, S. P. C. Govt. College, Ajmer, for laboratory and library facilities. We are thankful to M.D.S. University Ajmer for academic guidance. Finally we are grateful to U.G.C. for financial assistance. 
Funding: No funding sources

Conflict of interest: None declared

Ethical approval: The study was approved by the Institutional Ethics Committee of J. L. N Medical College, Ajmer (Rajasthan), India

\section{REFERENCES}

1. Nelson HD, Tyne K, Naik A, Bougatsos C, Chan BK, Humphrey L. Screening for breast cancer: an update for the U.S. Preventive Services Task Force. Ann Intern Med. 2009;151(10):727-37, W237-42.

2. Decker D. Prophylactic Mastectomy for familial breast cancer. JAMA. 1993;269:2608-9.

3. Otto SJ, Fracheboud J, Looman CW, Broeders MJ, Boer R, Hendriks JH. Initiation of population-based mammography screening in Dutch municipalities and effect on breast-cancer mortality: a systematic review. Lancet. 2003;361(9367):1411-7.

4. Gallicchio L, McSorley MA, Newschaffer CJ, Huang HY, Thuita LW, Hoffman SC, et al. Body mass, polymorphisms in obesity-related genes, and the risk of developing breast cancer among women with benign breast disease. Cancer Detect Prev. 2007;31(2):95-101.

5. Ghilardi N, Ziegler S, Wiestner A, Stoffel R, Heim MH, Skoda RC. Defective STAT signaling by the leptin receptor in diabetic mice. Proc Natl Acad Sci USA. 1996;93(13):6231-5.

6. Kaklamani VG, Sadim M, Hsi A, Offit K, Oddoux $\mathrm{C}$, Ostrer $\mathrm{H}$, et al. Variants of the adiponectin and adiponectin receptor 1 genes and breast cancer risk. Cancer Res. 2008;68(9):3178-84.

7. Liu CL, Chang YC, Cheng SP, Chern SR, Yang TL, Lee JJ, et al. The roles of serum leptin concentration and polymorphism in leptin receptor gene at codon109 in breast cancer. Oncology. 2007;72(12):75-81.

8. Mantzoros C, Petridou E, Dessypris N, Chavelas C, Dalamaga M, Alexe DM, et al. Adiponectin and breast cancer risk. J Clin Endocrinol Metab. 2004;89(3):1102-7.

9. Elwood, J. M., B. Cox, and A. K. Richardson. The effectiveness of breast cancer screening by mammography in younger women. The Online journal of current clinical trials (1993): 23-227.

10. Oleckno WA. Essential Epidemiology: Principles and applications. long Grove II: Waveland Press; 2002.

11. Snoussi K, Strosberg AD, Bouaouina N, Ben Ahmed S, Helal AN, Chouchane L. Leptin and leptin receptor polymorphisms are associated with increased risk and poor prognosis of breast carcinoma. BMC Cancer. 2006;6:38.

12. Szklo M, Nieto FJ .Epidemiology: Beyond the besics. $2^{\text {nd }}$ edition. Sudbury, MA: Jones and Bartlett Publishers; 2007.

13. Takahata C, Miyoshi Y, Irahara N, Taguchi T, Tamaki Y, Noguchi S. Demonstration of Adiponectin Receptors 1 and 2 mRNA expression in human breast cancer cells. Cancer Lett. 2006;54(13):113-9.

14. Tworoger SS, Eliassen AH, Kelesidis T, Colditz GA, Willett WC, Mantzoros C, et al. Plasma adiponectin concentrations and risk of incident breast cancer. J Clin Endocrinol Metab. 2007;6(23)119-21.

Cite this article as: Prakash B, Gahlot M, Yadav L. Epidemiological determinants of age for effective cervical and breast cancer screening in menopausal women. Int J Community Med Public Health 2016;3:494-7. 